\title{
RANCANG BANGUN PEMBANGKIT LISTRIK TENAGA SURYA SEBAGAI SUMBER LISTRIK UNTUK KAPAL PERIKANAN SKALA KECIL DI KABUPATEN PANGKEP, SULAWESI SELATAN
}

\section{DESIGN OF SOLAR POWER PLANTS AS A SOURCE OF ELECTRICITY FOR SMALL SCALE FISHERY, IN PANGKEP DISTRICT, SOUTH SULAWESI}

\author{
I Ketut Daging\#, M. Subroto Alirejo, I Putu Wirta Antara, Emil F. Dwiyatmo, Tri Wahyu \\ Permesinan Perikanan, Sekolah Tinggi Perikanan \\ Jl. AUP No. 1 Pasar Minggu, Jakarta Selatan, Indonesia \\ E-mail: i.daging@kkp.go.id
}

(Diterima: 18 Desember 2018; Diterima setelah perbaikan: 1 Agustus 2019; Disetujui: 1 Agustus 2019)

\begin{abstract}
ABSTRAK
Kebutuhan akan listrik untuk kalangan industri, perkantoran, perumahan, termasuk untuk kapal-kapal perikanan meningkat dengan pesat. Peningkatan kebutuhan listrik ini tidak diiringi dengan penambahan pasokan listrik. Energi surya dapat dijadikan alternatif penghasil energi listrik. Sel surya dapat mengkonversi langsung radiasi sinar matahari menjadi energi listrik (proses photovoltaic). Energi listrik yang dihasilkan dari sel surya dapat dimanfaatkan pada malam hari, dengan cara menyimpan energi listriknya ke baterai yang dikontrol oleh regulator pada siang hari. Pemanfaatan energi listrik di atas kapal dilakukan dengan menghubungkan inverter dari arus DC ke AC pada keluaran regulator. Hasil pengujian modul surya (photovoltaic) diperoleh daya terbesar yang dihasilkan dari jam 08:00-16:00 adalah pada jam 12:00 dengan daya yang dihasilkan sampai 45,76 watt. Pengukuran tegangan dan arus setiap jam dari rentang jam 08:00 - 16:00, diperoleh daya rata-ratanya sebesar 32,389 watt. Keluaran daya rata-rata selama 5 hari mencapai 32,386 watt.
\end{abstract}

KATA KUNCI: Listrik; panel surya; solar charge controller; baterai; inverter

\begin{abstract}
Electricity needed for industry, office, housing or on ships fisheries is greatly increased. The increase in demand for electricity is not accompanied by the additional power supply. Solar energy is chosen as an alternative energy source to generate electricity. A solar cell directly convert solar radiation into electrical energy (photovoltaic process). Electricity generated from solar energy is stored during the day in a battery controlled by a regulator, so it can be used at night. A current inverter is connected to regulator output. The highest power obtained from the solar power module (photovoltaic) generated between 08.00 to 16.00 hours is at 12:00 with power produced up to 45.76 watt. The measurement of voltage and current from 08.00 to 16.00 hours hourly basis, the average power generated is 32.389 watt. The average power output for 5 days reached 32.386 watt.
\end{abstract}

KEYWORDS: Electricity; solar panel; solar charge controller; battery; inverter

\section{PENDAHULUAN}

Kebutuhan akan listrik baik untuk kalangan industri, perkantoran, masyarakat umum maupun di kapal-kapal perikanan meningkat pesat. Kebutuhan akan listrik tidak hanya di darat, tetapi juga di laut dalam

\footnotetext{
\# Korespondensi: Sekolah Tinggi Perikanan

E-mail: i.daging@kkp.go.id
}

hal penerangan di kapal maupun pendukung dalam proses penangkapan ikan. Namun, peningkatan kebutuhan listrik ini tidak diiringi oleh penambahan jumlah pasokan listrik untuk konsumen, disebabkan semakin menipisnya ketersediaan bahan bakar minyak sehingga harganya semakin mahal sebagai bahan bakar 
menghidupkan generator untuk menghasilkan listrik (Suyanto, 1983). Generator adalah mesin yang mengubah energi gerak dari motor bakar menjadi energi listrik (Juhari, 2013).

Pemakaian listrik di atas kapal adalah hal yang sangat penting karena sangat mendukung dalam proses penangkapan terutama penerangan di malam hari, terutama oleh kapal ikan yang membutuhkan penerangan dalam proses penangkapan. Setiap harinya bahan bakar terpakai untuk menghidupkan generator, sehingga pengeluaran bertambah, sementara pendapatan nelayan tidak tentu apalagi saat cuaca buruk memperoleh hasil sangat sedikit. Harga bahan bakar yang semakin mahal menambah beban pengeluaran bagi nelayan. Kebutuhan bahan bakar bukan hanya untuk mesin induk saja tetapi juga untuk menghidupkan generator. Hal ini adalah masalah besar bukan hanya untuk nelayan saja tapi untuk kita semua yang memerlukan listrik.

Berdasarkan beberapa permasalahan di atas, penulis memiliki alternatif solusi yang diharapkan dapat menghindarkan krisis listrik, terutama untuk kapalkapal perikanan skala kecil yang tidak menggunakan generator karena mengurangi jumlah pengeluaran untuk penerangan setiap malamnya. Kapal-kapal seperti ini umumnya, hanya memakai alat penerangan sekadarnya saja seperti senter. Atas dasar inilah penulis mencoba untuk merancang sebuah pembangkit listrik dengan memanfaatkan energi cahaya matahari (energi surya). Energi listrik dari tenaga surya ini dimanfaatkan sebagai energi listrik alternatif khususnya bagi kapal-kapal perikanan yang tidak menggunakan generator. Pemanfaatan energi surya ini dipilih karena energi matahari termasuk salah satu jenis energi terbarukan (Boyle, 2004) dan Indonesia merupakan negara tropis yang berada di jalur khatulistiwa sehingga berlimpah sinar matahari sepanjang tahun (Anwar, 2016; Akhmad, 2011; Anggara, et al, 2014). Penulis dalam penelitian ini menggunakan proses fotovoltaik, yaitu dengan cara mengkonversikan secara langsung energi surya menjadi energi listrik (Bhatia, 2014). Proses ini hanya dapat dilakukan dengan menggunakan suatu bahan yang umum dinamakan dengan nama sel surya (solar cell) yang dapat bekerja dengan optimal jika sel surya ini mendapat paparan sinar matahari (Deni, 2012; Khulaemi, 2016; Nasution, 2015).

Penulis berharap kapal-kapal perikanan yang kecil maupun yang besar berminat dan dapat memanfaatkan energi alam yang ada seperti energi matahari dengan rancangan PLTS ini sehingga mengurangi beban biaya yang dikeluarkan oleh para nelayan.
Tujuan penelitian ini adalah untuk mengetahui komponen utama Pembangkit Listrik Tenaga Surya beserta fungsinya, mengetahui cara kerja Pembangkit Listrik Tenaga Surya, mengetahui prosedur perancangan Pembangkit Listrik Tenaga Surya di kapal perikanan, perakitan Pembangkit Listrik Tenaga Surya di kapal perikanan, menguji Pembangkit Listrik Tenaga Surya terhadap daya yang dihasilkan oleh Panel Surya kapasitas 50 WP (Waat Peak) sebagai sumber listrik (Hasan, 2012; Suryatmo, 2014).

\section{BAHAN DAN METODE}

Pelaksanaan penelitian dilaksanakan selama enam bulan mulai tanggal 16 Oktober 2017 sampai Mei 2018. Penelitian dilakukan di kapal KM. AAS Kendari Sulawesi Tenggara dan KM Putri Indah Pangkep Sulawesi Selatan.

Alat dan bahan yang digunakan dalam penelitian ini adalah avometer, ampermeter, obeng, kalkulator, pencatat waktu, alat tulis, kamera, 2 unit kapal nelayan, panel surya, inverter, baterai, kontroler, kabel, lampu LED, dan fish finder.

Metode pengumpulan data dengan melakukan perancangan dan pemasangan panel surya untuk mendapatkan data dan informasi yang sesungguhnya, juga melakukan wawancara dengan pihak-pihak yang berkompeten serta mengadakan studi literatur sebagai bahan referensi.

\section{HASIL DAN PEMBAHASAN}

Kapal-kapal perikanan yang berada di Kendari Sulawesi Tenggara dan Sulawesi Selatan pada umumnya tidak semua dilengkapi dengan generator pembangkit tenaga listrik untuk kebutuhan penerangan dan untuk mengaktifkan peralatan navigasi. Hal ini terutama pada kapal-kapal yang berukuran skala kecil namun daerah penangkapannya cukup jauh, dan setiap tripnya tidak hanya 2-3 hari, tapi setiap tripnya terkadang sampai seminggu.Untuk penerangan di jenis kapal tersebut jika menggunakan generator, akan lebih banyak kerugian daripada keuntungan yang dirasakan.

Pertama, penggunaan generator di atas kapal akan memakan tempat, kedua pengeluaran atau biaya untuk bahan bakar lebih banyak. Hal ini karena kebutuhan bahan bakar selain untuk mesin penggerak ditambah lagi untuk membangkitkan listrik dari generator. Kondisi ini menyebabkan biaya pengeluaran bertambah, sementara untuk pendapatan yang diperoleh dari pelayaran tidak menentu. Kapal yang digunakan adalah kapal yang berukuran kecil di mana awak kapal hanya 2 atau 3 orang, sehingga listrik yang digunakan juga tidak begitu banyak. Oleh karena itu, 
penulis mengambil alternatif untuk merancang bangun pembangkit listrik tenaga surya di kapal yang berukuran kecil.

Kapal perikanan dapat memanfaatkan sumber energi yang berlimpah seperti energi dari sinar matahari yang dapat dimanfaatkan untuk kegunaan lainnya. pemanfaatan energi sinar matahari ini dilakukan menggunakan alat yang disebut panel surya yang berfungsi sebagai pembangkit tenaga listrik alternatif di kapal nelayan.

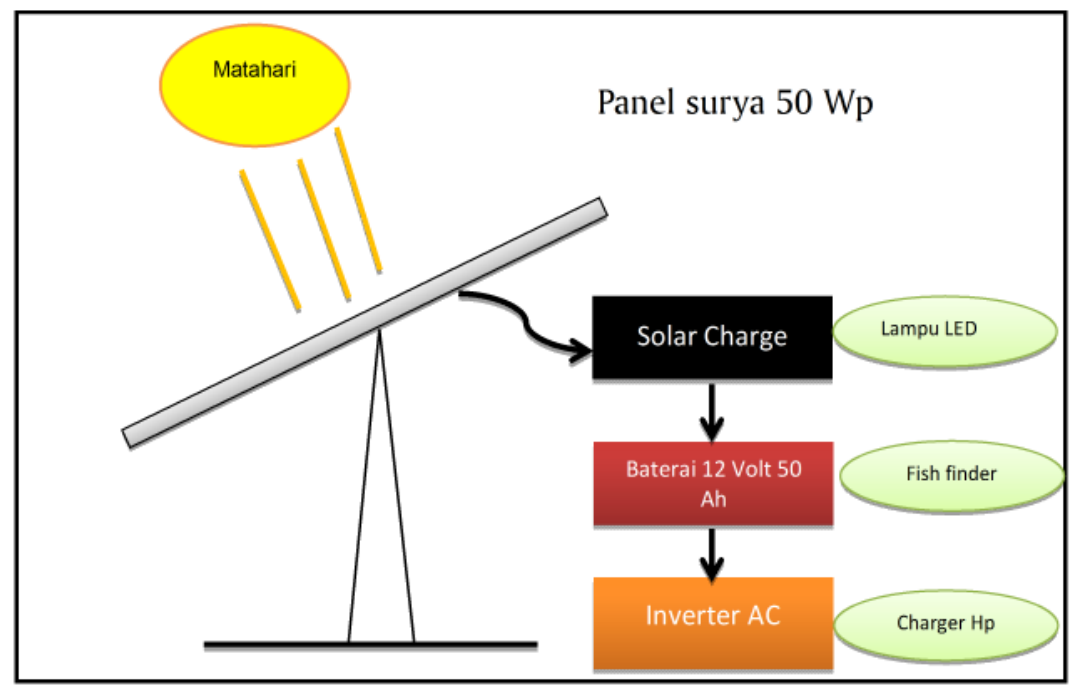

Gambar 1. Diagram Blok Pembangkit Listrik Tenaga Surya.

Figure 1. Block diagram of Solar Power Plant.

Komponen utama pembangkit listrik tenaga surya di kapal perikanan yang diteliti terdiri atas panel surya, charge controller, baterai, dan inverter (Boxwell, 2017). Penjelasan masing-masing komponennya adalah sebagai berikut:

\section{Panel surya / solar cell}

Panel surya adalah alat yang digunakan untuk menyerap dan mengubah sinar matahari menjadi energi listrik. Sinar matahari mengandung energi dalam bentuk foton, di mana saat foton mengenai permukaan sel surya, elektronnya akan tereksitasi dan menimbulkan aliran listrik. Peristiwa ini disebut sebagai peristiwa Fotovoltaic atau fotoelektrik (Penick \& Louk, 1998; Fahrenbruch \& Bube, 2012). Sel surya dapat tereksitasi karena terbuat dari material semikonduktor yang mengandung unsur silikon. Silikon ini terdiri dari dua jenis lapisan sensitif yaitu lapisan positif (tipe-P) dan lapisan negatif (Tipe-N).

\section{Solar Charge Controller (SCC)}

Charge Controller adalah peralatan elektronik yang digunakan untuk mengatur arus searah yang diisi ke baterai dan yang diambil dari baterai ke beban (Rashid, 2011). Solar charge controller mengatur overcharging (kelebihan pengisian - karena baterai sudah 'penuh') dan kelebihan voltase dari panel surya. Kelebihan voltase dan pengisian akan mengurangi umur baterai.
Charge controller menerapkan teknologi Pulse width modulation (PWM) untuk mengatur fungsi pengisian baterai dan pembebasan arus dari baterai ke beban. Panel surya 12 Volt umumnya memiliki tegangan output 16 - 21 Volt. Jadi, tanpa solar charge controller, baterai akan cepat rusak oleh overcharging dan terjadi ketidakstabilan tegangan. Baterai umumnya di-charge pada tegangan $14-14,7$ Volt.

Beberapa fungsi detail dari solar charge controller adalah mengatur arus untuk pengisian ke baterai, menghindari overcharging, dan overvoltage. Solar charge controller juga mengatur arus yang dibebaskan/ diambil dari baterai agar baterai tidak 'full discharge', dan overloading (Simarmata, 2016). Untuk membeli solar charge controller yang harus diperhatikan adalah: Voltage 12 Volt DC / 24 Volt DC, kemampuan (dalam arus searah) dari controller, misalnya 5 Ampere, 6 Ampere, 10 Ampere, dsb dan Full charge dan low voltage cut.

Pada umumnya terdapat 6 terminal pada sebuah SCC, yaitu 2 terminal untuk arus dari panel surya, 2 terminal untuk menghubungkannya pada aki, dan 2 terminal lagi untuk penggunaan lampu. Untuk efisiensi yang lebih tinggi, gunakan lampu DC seperti lampu LED. 


\section{Baterai (accu)}

Baterai adalah alat yang menyimpan daya listrik yang dihasilkan oleh panel surya yang tidak segera digunakan oleh beban. Daya yang disimpan dapat digunakan saat periode radiasi matahari rendah atau pada malam hari. Komponen baterai kadang-kadang dinamakan akumulator (accumulator).

Baterai memenuhi dua tujuan penting dalam sistem fotovoltaik, yaitu untuk memberikan daya listrik kepada sistem ketika daya tidak disediakan oleh array panel-panel surya, dan untuk menyimpan kelebihan daya yang dihasilkan oleh panel-panel setiap kali daya itu melebihi beban yang digunakan. Baterai mengalami proses siklis menyimpan dan mengeluarkan, tergantung pada ada atau tidak adanya sinar matahari. Selama waktu adanya matahari, panel surya menghasilkan daya listrik. Daya listrik yang tidak digunakan dengan segera akan diisi ke dalam baterai. Selama waktu tidak adanya matahari, kebutuhan daya listrik diambil dari baterai.

\section{Inverter}

Inverter adalah perangkat elektrik yang digunakan untuk mengubah arus listrik searah (DC) dari perangkat seperti baterai, panel surya/solar cell menjadi arus listrik bolak-balik (AC). Penggunaan inverter pada sistem Pembangkit Listrik Tenaga Surya (PLTS) adalah untuk menyediakan arus AC (Alternating Current) pada perangkat seperti charger handphone. Inverter dipasang langsung terminal positif dan negatifnya pada terminal baterai.

Hal-hal yang perlu dipertimbangkan dalam pemilihan inverter, yaitu usahakan memilih inverter yang beban kerjanya (dalam Watt) mendekati dengan beban yang hendak kita gunakan agar efisiensi kerjanya maksimal, serta memiliki Input DC 12 Volt atau 24 Volt.

\section{Prosedur Perakitan}

Tahapan dan alur perakitan komponen PLTS di kapal nelayan dilakukan sebagai berikut (Gambar 2):

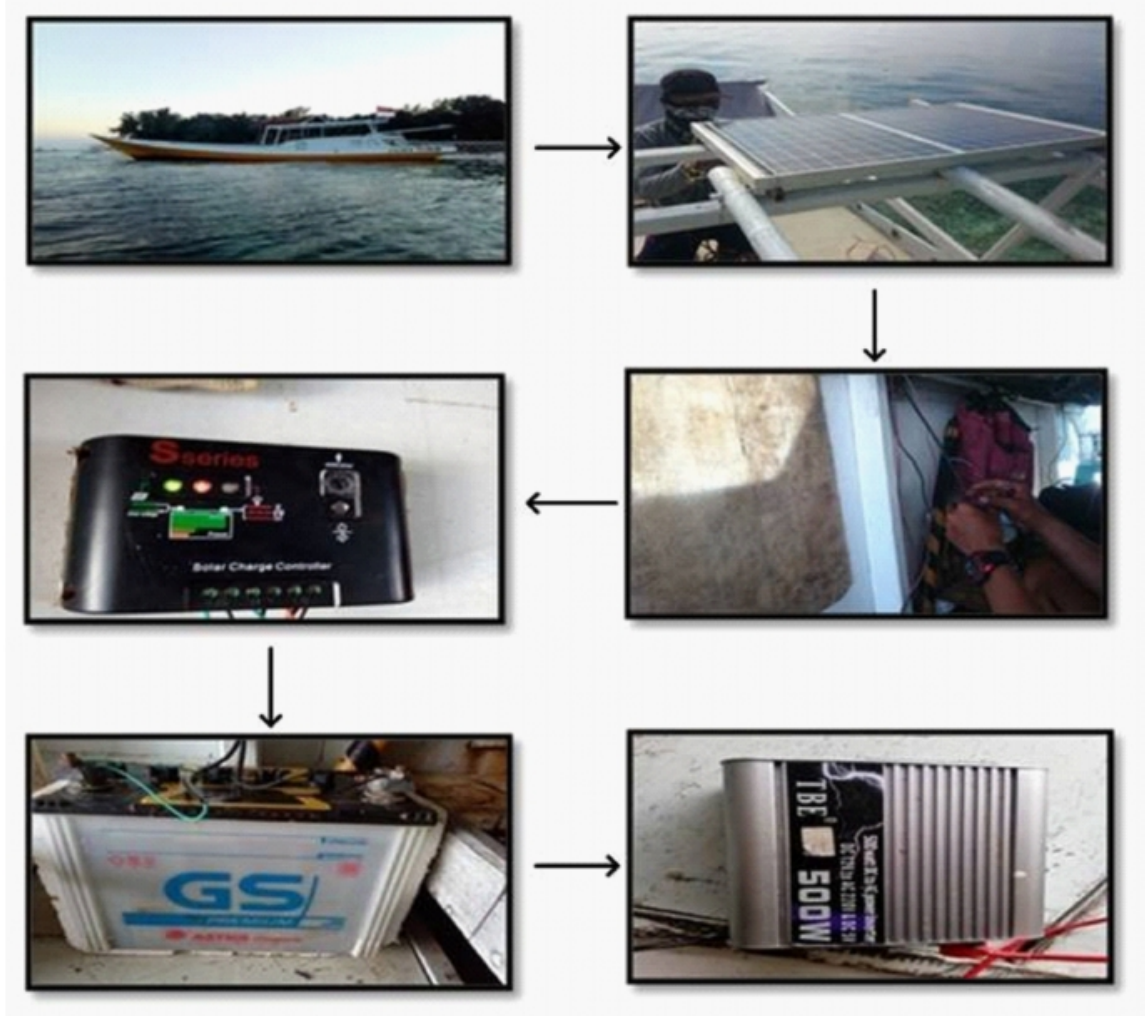

Gambar 2. Alur Perakitan Komponen PLTS

Figure 2. Assembly of solar power plant equipments

Tahapan pelaksanaan perakitan komponen pembangkit listrik tenaga surya di kapal perikanan skala kecil dimulai dari survey, pemasangan komponen, serta pemasangan beban yang akan digunakan pada kapal tersebut.

\section{Pengujian}

Setelah semua komponen PLTS terpasang dengan baik, selanjutnya dilakukan uji coba terhadap daya listrik yang dihasilkan PLTS dengan menyalakan beberapa lampu, fish finder dan juga mencharger 
handphone. Tujuan dari uji coba ini adalah untuk mengetahui apakah rangkaian PLTS yang terpasang benar-benar bekerja dan terpasang dengan baik. Berikut adalah tahapan uji coba daya listrik yang dilakukan (Gambar 3 sampai Gambar 5).

Gambar 3 adalah pengujian penyalaan lampu LED berdaya 3 watt untuk penerangan di kapal KM Putri Indah.
Gambar 4 adalah uji coba penyalaan fish finder di kapal KM Putri Indah. Fish finder ini memiliki daya 7,6 Watt, Voltage 10-36 V DC.

Gambar 5 adalah pengujian mengisi daya handphone dengan menggunakan inverter sebagai pengubah arus DC menjadi arus AC.

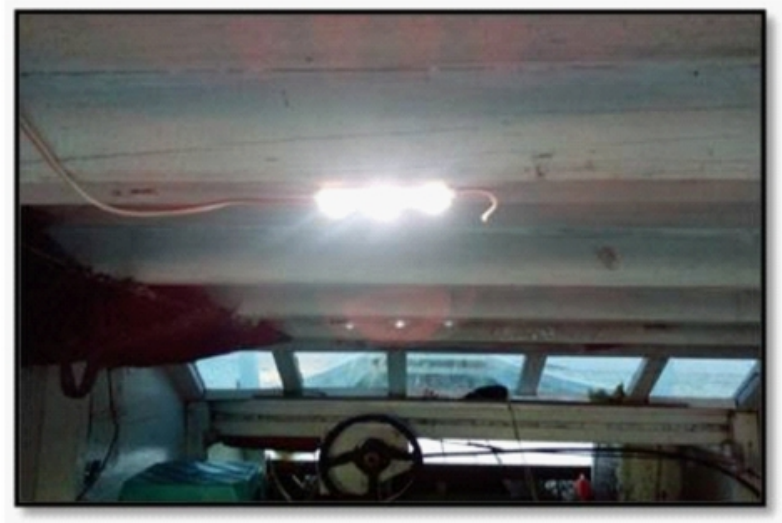

Gambar 3. Uji Coba Penerangan Lampu LED.

Figure 3. Performance test of Solar Power Plant using LED Lamp.

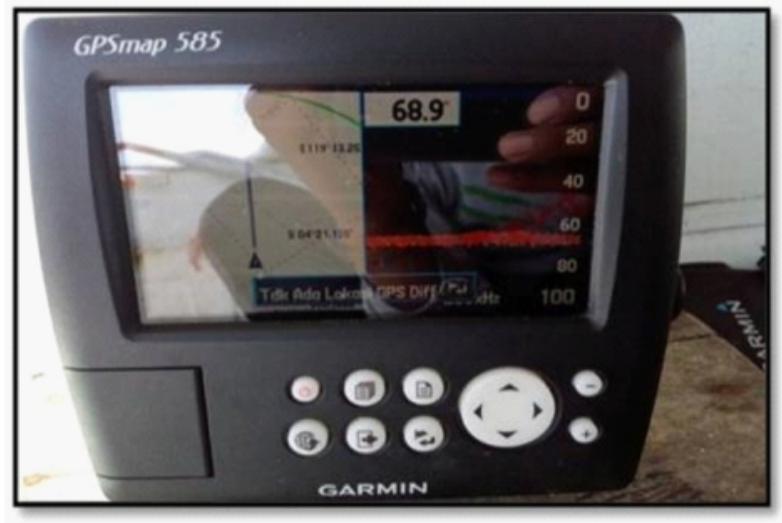

Gambar 4. Uji Coba Pemanfaatan untuk Fish finder.

Figure 4. Performance test of Solar Power Plant using Fish Finder device.

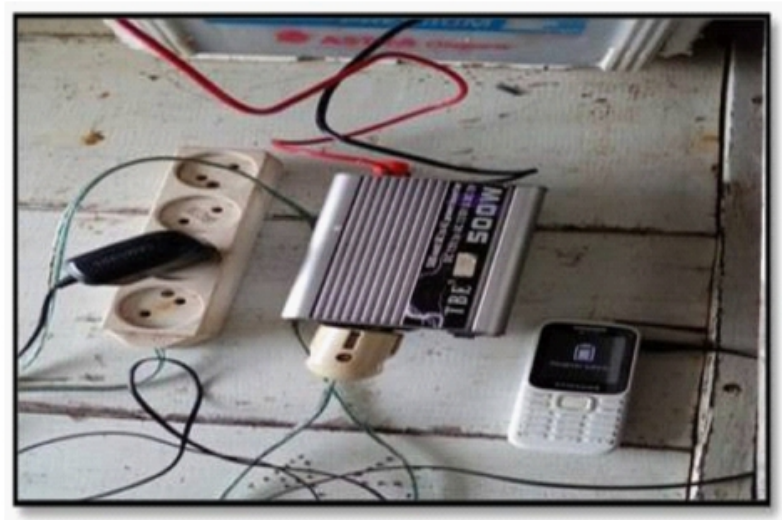

Gambar 5. Uji Coba untuk Beban AC Menggunakan Inverter.

Figure 5. Testing for AC Load using Inverter. 


\section{Pengukuran Tegangan (V) dan Arus (A)}

Pengambilan data yang pertama dilakukan dengan alat ukur avometer digital pada kapal KM. Putri Indah. Data yang diambil adalah tegangan (V) dan arus (A) yang bertujuan untuk mengetahui seberapa besar tegangan (V) dan arus (A) pada selang waktu tertentu.
Pengambilan data dimulai dari pukul 08.00 hingga pukul 16.00 karena pada rentang jam tersebut intensitas sinar matahari sebagai sumber energi utama pembangkit listrik tenaga surya tersedia dengan cukup. Hasil pengambilan data pada Tabel 1 .

Tabel 1. Hasil pengukuran tegangan (V) dan arus (A) listrik selama 5 hari

Table 1 . Measurement of voltage $(\mathrm{V})$ and current (A) for 5 days

\begin{tabular}{|c|c|c|c|c|c|c|c|c|c|c|c|}
\hline \multirow{2}{*}{ No } & \multirow{2}{*}{ Jam } & \multicolumn{2}{|c|}{$\begin{array}{c}\text { Selasa/03- } \\
\text { 04/2018 }\end{array}$} & \multicolumn{2}{|c|}{$\begin{array}{c}\text { Rabu/04-04- } \\
2018 \\
\end{array}$} & \multicolumn{2}{|c|}{$\begin{array}{c}\text { Kamis/05- } \\
04-2018\end{array}$} & \multicolumn{2}{|c|}{$\begin{array}{c}\text { Jumat/06- } \\
\text { 04-2018 } \\
\end{array}$} & \multicolumn{2}{|c|}{$\begin{array}{c}\text { Sabtu/07-04- } \\
2018\end{array}$} \\
\hline & & $\begin{array}{l}\text { Teg } \\
\text { (V) }\end{array}$ & $\begin{array}{c}\text { Arus } \\
\text { (A) }\end{array}$ & $\begin{array}{l}\text { Teg } \\
(\mathrm{V})\end{array}$ & $\begin{array}{c}\text { Arus } \\
(A)\end{array}$ & $\begin{array}{l}\text { Teg } \\
(\mathrm{V})\end{array}$ & $\begin{array}{c}\text { Arus } \\
\text { (A) }\end{array}$ & $\begin{array}{l}\text { Teg } \\
(\mathrm{V})\end{array}$ & $\begin{array}{c}\text { Arus } \\
\text { (A) }\end{array}$ & $\begin{array}{l}\text { Teg } \\
(\mathrm{V})\end{array}$ & $\begin{array}{c}\text { Arus } \\
\text { (A) }\end{array}$ \\
\hline 1 & 08:00 & 20,5 & 1,1 & 20,6 & 1,0 & 20,2 & 1,3 & 20,6 & 1,1 & 20,8 & 0,9 \\
\hline 2 & 09:00 & 18,5 & 1,7 & 18,2 & 1,0 & 18,7 & 1,6 & 18,9 & 1,8 & 20,1 & 0,9 \\
\hline 3 & 10:00 & 17,3 & 2,0 & 17,5 & 1,9 & 18,8 & 1,5 & 17,4 & 2,1 & 19,5 & 1,5 \\
\hline 4 & $11: 00$ & 16,9 & 2,8 & 16,7 & 2,9 & 19,1 & 1,3 & 16,4 & 2,5 & 19,2 & 1,4 \\
\hline 5 & $12: 00$ & 16,8 & 2,9 & 16,5 & 2,8 & 16,7 & 2,7 & 16,3 & 2,9 & 17,3 & 2,4 \\
\hline 6 & $13: 00$ & 17,1 & 2,5 & 17,2 & 2,4 & 16,8 & 2,6 & 17,2 & 2,1 & 17,7 & 2,0 \\
\hline 7 & $14: 00$ & 17,3 & 2,3 & 17,5 & 2,1 & 17,6 & 2,2 & 17,4 & 2,0 & 18,1 & 1,2 \\
\hline 8 & $15: 00$ & 19,5 & 1,4 & 19,1 & 1,5 & 19,2 & 1,4 & 19,3 & 1,2 & 17,9 & 1,9 \\
\hline 9 & $16: 00$ & 20,1 & 1,3 & 20,0 & 1,2 & 20,2 & 1,1 & 19,9 & 1,2 & 20,5 & 1,4 \\
\hline
\end{tabular}

Berdasarkan tabel di atas, tegangan dan arus berubah tergantung dari intensitas cahaya matahari yang diterima oleh panel surya. Data pengujian menunjukkan bahwa intensitas tertinggi selama pengujian selama 5 hari yaitu terjadi pada saat hari Selasa tanggal 03-04-2018 antara jam 11:00 - 12:00. Ketika itu sel surya mampu menghasilkan tegangan 16,8 Volt dan Arus 2,9 Ampere. Tingkat intensitas cahaya matahari yang diterima sel surya sebanding dengan arus yang dihasilkan oleh sel surya (Rosenblum, 1991). Antara jam 11.00 hingga 12.00 merupakan waktu puncak intensitas sinar matahari yang diterima oleh sel surya, sehingga hasil yang diperoleh berkorelasi dengan besarnya arus yang dihasilkan.

Perhitungan daya yang dihasilkan dihitung menggunakan persamaan (1), sehingga diperoleh:

$$
\begin{aligned}
& \mathrm{P}=\mathrm{V} . \mathrm{I} \\
& \mathrm{P}=(16,8)(2,9) \\
& \mathrm{P}=48,72 \text { watt }
\end{aligned}
$$

\section{Rata - Rata Watt Perhari}

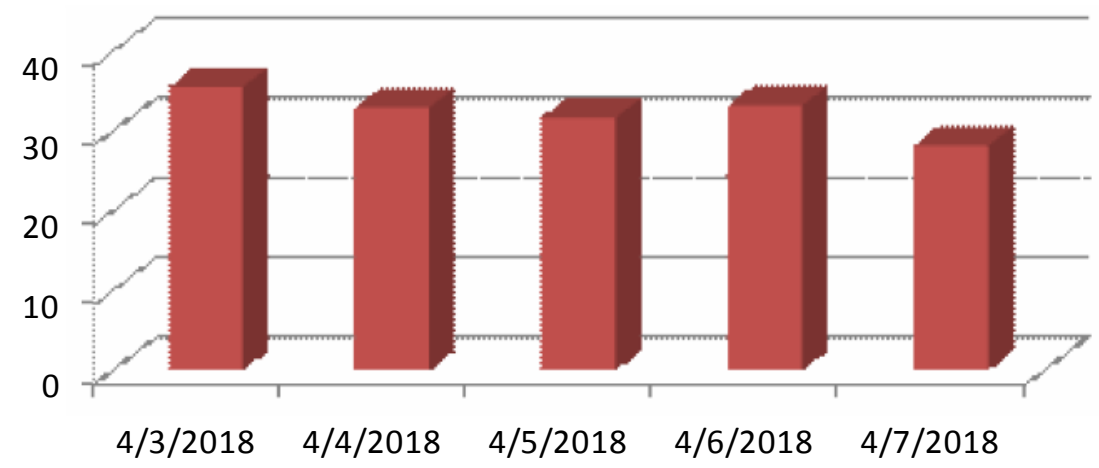

Gambar 6. Grafik daya listrik rata-rata dari hasil perhitungan selama 5 hari. Figure 6 . Average electricity power produced for 5 days. 
Gambar 6 yang merupakan rata-rata daya setiap harinya selama pengukuran 5 hari menunjukkan nilai dayanya sekitar 28 sampai 35 watt.
Gambar 7 menunjukkan daya terbesar yang dihasilkan dari jam 08:00-16:00 tercatat pada jam 11.00-12.00 sebesar 45,76 Watt. Dari perhitungan diperoleh daya pada setiap jam pengukuran yaitu sebanyak 9 kali pengukuran, sehingga daya reratanya sebesar :

$$
\begin{aligned}
\mathrm{P}_{\text {rerata }} & =\frac{\mathrm{P}_{1}+\mathrm{P}_{2}+\mathrm{P}_{3}+\ldots \ldots+\mathrm{P}_{9}}{9} \ldots \ldots \ldots \ldots \ldots \ldots \ldots \ldots \ldots \ldots \ldots \ldots \ldots \ldots \ldots \ldots \ldots \ldots \ldots \ldots \ldots \ldots \ldots \ldots \ldots \ldots \ldots \ldots \ldots \ldots \ldots \\
\mathrm{P}_{\text {rerata }} & =\frac{22,158+26,336+32,368+37,692+45,76+39,846+34,356+28+24,986}{9} \\
\mathrm{P}_{\text {rerata }} & =\frac{291,502}{9}=32,389 \mathrm{watt}
\end{aligned}
$$

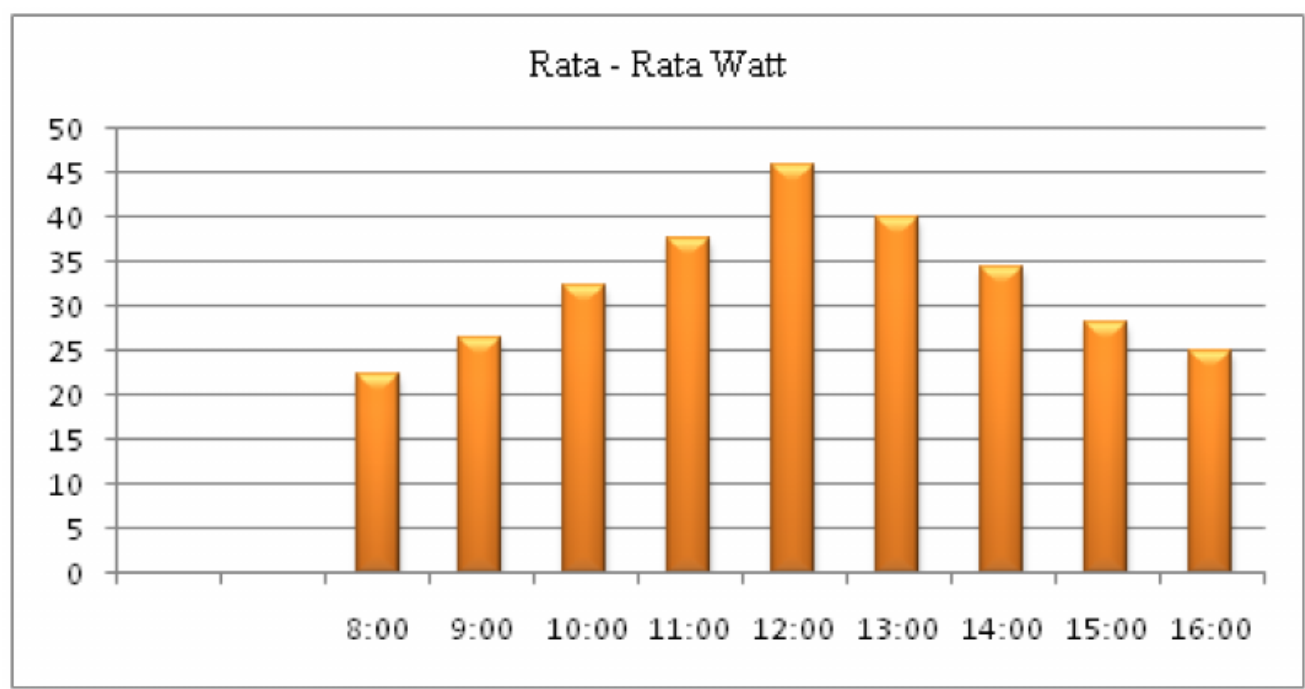

Gambar 7. Grafik watt rata-rata setiap jam yang dihasilkan panel surya.

Figure 7. Graphic of average power produced by solar panel, hourly basis.

\section{KESIMPULAN DAN SARAN}

\section{Kesimpulan}

Komponen utama pembangkit listrik tenaga surya terdiri dari: Panel surya, solar charge controller, baterai, dan inverter. Panel surya adalah komponen pokok listrik tenaga surya, karena dapat mengkonversikan langsung radiasi sinar matahari menjadi energi listrik (proses photovoltaic). Agar energi surya dapat digunakan pada malam hari, maka pada siang hari energi listrik yang dihasilkan disimpan terlebih dahulu ke baterai yang dikontrol oleh regulator. Keluaran regulator langsung dihubungkan dengan inverter dari arus DC ke AC. Daya maksimal yang dihasilkan panel surya dari pengujian jam 08:00-16:00 adalah pada saat jam 10:00 - 13:00. Intensitas tertinggi selama pengujian selama 5 hari yaitu terjadi pada saat hari Selasa tanggal 03-04-2018 antara jam 11:00 12:00. Pada saat itu sel surya mampu menghasilkan tegangan 16,8 Volt dan Arus 2,9 Ampere, sehingga daya keluarannya adalah: $P=V . I=(16,8)(2,9)=48,72$ Watt. Daya terbesar yang dihasilkan panel surya selama jam 08:00-16:00 sebesar 45,76 Watt. Hasil perhitungan daya listrik rata-rata setiap jamnya sebesar 32,389 Watt. Pada pengukuran tegangan makin besar angka Volt maka makin kecil ampere yang dihasilkan, dan makin besar hasil pengukuran ampere maka semakin kecil volt sehingga daya yang dihasilkan makin besar.

\section{Saran}

Sebelum melakukan perancangan pembangkit listrik tenaga surya diperlukan pengetahuan tentang komponen utama dan fungsinya masing-masing. Apabila salah satu komponen bermasalah atau rusak sebaiknya segera diperbaiki atau diganti untuk menjaga komponen tetap memiliki kinerja baik. Merakit atau memasang komponen pembangkit listrik tenaga surya tidak boleh menghubungkan output dari 
panel surya langsung ke baterai, sebaiknya melalui solar charge controller. Waktu pengisian daya listrik yang maksimal oleh panel surya sebaiknya pada jam 10:00-13:00 siang hari. Pemasangan pembangkit listrik tenaga surya di atas kapal sebaiknya dipasang pada posisi panel surya secara horizontal untuk mendapatkan sinar matahari yang lebih optimal.

\section{DAFTAR PUSTAKA}

Akhmad, K, (2011), Pembangkit Listrik Tenaga Surya dan Penerapanya untuk Daerah Terpencil, Jurnal Dinamika Rekayasa, 1 (1).

Anggara, I.W.G.A, Kumara, I.N.S, Giriantari, I.A.D, (2014), Studi Terhadap Unjuk Kerja Pembangkit Listrik Tenaga Surya 1,9 kW di universitas Udayana Bukit Jimbaran Spektrum, 1 (1).

Anwar. (2016). Analisis Desain Sistem Pembangkit Listrik Tenaga Surya Kapasitas 50 WP. Jakarta.

Bathia, S. C. (2014). Energy Resources and Their Utilisation. Advanced Renewable Energy Systems. $1-31$.

Boxwell, M. (2017). Solar Electricity Handbook (11th ed.). Birmingham: Greenstream Publishing Ltd.

Boyle, G. (2004). Renewable Energy. Oxford: Oxford University Press.

Deni, A. (2012). Prospek PLTS di Indonesia, Energi Indonesia (Artikel-artikel Populer), Fisika LIPI, Jakarta.

Fahrenbruch, A., \& Bube, R. (2012). Fundamentals of Solar Cells: Photovoltaic Solar Energy Conversion. Elsevier.
Hasan. H, (2012), Perancangan Pembangkit Listrik Tenaga Surya di Pulau Saugi, Jurnal Riset dan Teknologi Kelautan.

Juhari. (2013). Generator. Kementerian Pendidikan dan kebudayaan Republik Indonesia.

Khulaemi, A. (2016). Modul Pemeliharaan Listrik Tenaga Surya (PLTS). Jakarta: PPSDM Ketenagalistrikan, Energi Baru, Terbarukan, dan Konservasi Energi.

Nasution, Z. (2015). Modul Komponen PLTS Terpusat. Jakarta: PPSDM Ketenagalistrikan, Energi Baru, Terbarukan, dan Konservasi Energi.

Penick, T. \& Louk, B. (1998). Photovoltaic Power Generation. Gale Greenleaf.

Rashid, M. H. (2011). Power Electronics Circuits, Devices, and Application (3rd ed.), Prentice Hall.

Rosenblum, L. (1991). Photovoltaic Sistem Design. Solar Energy in Agriculture. New York: Elsevier Science Publishing Company.

Simarmata, T. (2016). Modul Teori Dasar Listrik. Jakarta: PPSDM Ketenaga listrikan, Energi Baru, Terbarukan, dan Konservasi Energi.

Suryatmo F. (2014). Dasar-dasar Teknik Listrik. Jakarta: Rineka Csipta.

Suyanto. (1983). Pesawat Kapal II. Jakarta: Penerbit AUP. 